\title{
Assessing sediment contamination using six toxicity assays
}

\author{
G. Allen BURTON Jr.*, Renato BAUDO ${ }^{1)}$, Monica BELTRAMI ${ }^{1)}$, and Carolyn ROWLAND \\ Institute for Environmental Quality, Wright State University, Dayton, Ohio, USA \\ ${ }^{1)}$ CNR. Istituto Italiano Idrobiologia. Largo Tonolli 50. I 28922 Pallanza, Italy \\ *e-mail corresponding author: allen.burton@wright.edu
}

\begin{abstract}
An evaluation of sediment toxicity at Lake Orta, Italy was conducted to compare a toxicity test battery of 6 assays and to evaluate the extent of sediment contamination at various sediment depths. Lake Orta received excessive loadings of copper and ammonia during the 1900's until a large remediation effort was conducted in 1989-90 using lime addition. Since that time, the lake has shown signs of a steady recovery of biological communities. The study results showed acute toxicity still exists in sediments at a depth of 5 $\mathrm{cm}$ and greater. Assays that detected the highest levels of toxicity were two whole sediment exposures ( 7 d) using Hyalella azteca and Ceriodaphnia dubia. The Microtox ${ }^{R}$ assay using pore water was the third most sensitive assay. The Thamnotox, Rototox, Microtox solid phase, and Seed Germination-Root Elongation (pore and solid phase) assays showed occasional to no toxicity. Based on similarity of responses and assay sensitivity, the two most useful assays were the $\mathrm{C}$. dubia (or $\mathrm{H}$. azteca) and Microtox pore water. These assays were effective at describing sediment toxicity in a weight-of-evidence approach.
\end{abstract}

Key words: bioassays, pore water, interstitial water

\section{INTRODUCTION}

The majority of chemicals discharged into aquatic systems eventually end up in sediments. Sediments are perhaps the most important component of aquatic ecosystems, being the principal site of biogeochemical cycling and the foundation of the food web. The microbial, meiofaunal and macrofaunal communities which reside in sediments process organic matter and serve as food sources for higher trophic levels, including humans. It is now well established that depositional sediments near urban and agricultural areas are frequently contaminated with organic and inorganic contaminants that have severely impacted water quality. One such site is Lake Orta, Italy. This lake was heavily contaminated with copper and ammonia from a rayon production facility during the early to mid-1900's. Between 1989 and 1990 lime was applied to the lake in an effort to restore water quality by neutralising the acidic $\mathrm{pH}$. The treatment resulted also in the sequestration of copper as copper carbonates settled into the sediments. Since that period, the Istituto Italiano di Idrobiologia has been studying the lake's recovery.

A wide variety of methods exist by which sediment contamination can be assessed (Tab. 1). During the past decade it has become apparent from numerous water and sediment quality assessment studies that no one approach (e.g., chemical-specific criteria) can be routinely used to accurately determine or predict ecosystem health and beneficial use impairment. In Ohio, evaluation of indigenous biota showed $36 \%$ of the impaired stream segments could not be detected using chemical criteria alone (Plafkin et al. 1989; USEPA 1990b). Re- alization of the inadequacy of nationwide criteria prompted the U.S. Environmental Protection Agency (EPA) to look for other site-specific criteria modifications. Numerous studies of bulk sediment contaminant concentrations failed to show significant correlations of toxic effects to test species (Burton 1991). Chemical criteria provide a benchmark from which to evaluate the significance of contaminant concentration and direct further monitoring resources. Biological assessments indicate if the aquatic community is of a pollutionhabitat tolerant or sensitive nature by showing the effect of long-term exposures. By considering habitat influence and comparing to reference sites, evaluations of ecological integrity (health) can be made. Finally, the fourth major assessment component is toxicity. Biosurvey data may not detect subtle, short-term, or recent toxic effects due to the natural variation (spatial and temporal) occurs in aquatic communities. Toxicity testing also separates out habitat effects relatively well, focusing on the availability of chemical contaminants. The EPA (1990a) states that when any assessment approach (i.e., chemical-specific, toxicity, or bio-survey) show water quality standards are not being achieved, regulatory action should be taken.

A wide variety of toxicity assays exist for assessing sediments (Burton 1991, 1992). While each of these assays has its own merit because it assesses the response of a unique species, they vary dramatically in their sensitivity and discriminatory ability (Burton et al. 1996) and their usefulness as a surrogate indicator of receiving water populations and communities (LaPoint et al. 2000). There are a variety of traits that make for a good assay (Burton 1991). One of the nonscientific traits of importance is the issue of resource requirements (i.e., 
Tab. 1. Components of an Integrated Approach to Assess Receiving Water Quality (modified from USEPA 1990a).

\begin{tabular}{|c|c|c|}
\hline Control Approach: & What It Provides: & What It Doesn't Provide: \\
\hline Chemical-Specific & $\begin{array}{l}\text { Human health protection } \\
\text { Complete toxicology } \\
\text { Straightforward treatability } \\
\text { Familiarity with control } \\
\text { Persistency coverage } \\
\text { Regulatory ease }\end{array}$ & $\begin{array}{l}\text { All toxics present } \\
\text { Bioavailability } \\
\text { Interactions of mixtures (e.g., additivity) } \\
\text { Poor trend analysis } \\
\text { Accurate toxicology (false assumptions) }\end{array}$ \\
\hline Toxicity & $\begin{array}{l}\text { Aggregate toxicity } \\
\text { All toxics present } \\
\text { Bioavailability } \\
\text { Accurate toxicology } \\
\text { Good trend analysis } \\
\text { Lab or in situ testing }\end{array}$ & $\begin{array}{l}\text { Human health protection } \\
\text { Complete toxicology } \\
\text { (few species may be tested) } \\
\text { Simple treatability } \\
\text { Persistency coverage }\end{array}$ \\
\hline Bioassessments & $\begin{array}{l}\text { Actual receiving water effects } \\
\text { Trend analysis } \\
\text { Severity of impact } \\
\text { Total effect of all sources }\end{array}$ & $\begin{array}{l}\text { Critical flow effects } \\
\text { Straightforward interpretation of results } \\
\text { Cause of impact } \\
\text { Differentiation of sources }\end{array}$ \\
\hline
\end{tabular}

time, expertise, cost). For this reason, toxicity assays that are inexpensive, short-term and simple to perform are often desirable for environmental assessments. However, there is a concern that these short term assays may be less predictive of receiving water conditions and/or biological community responses or not ecologically relevant. The following study was designed to address this concern by comparing three resource efficient "test kit" assays with two more conventional toxicity assays. A second objective was to evaluate the degree of sediment toxicity existing in Lake Orta. The study hypotheses were as follows:

- Acute toxicity of Lake Orta sediments decreases in the upper sediment surface layers and has distinct vertical layers of contamination.

- Toxicity of Lake Orta surficial sediments is significant and can best be defined using a multi-test battery of toxicity assays,

- Toxicity assays will vary widely in their responses and some may be insensitive to the presence of metal contamination.

\section{METHODS}

\subsection{Site and station description}

Lake Orta has received industrial pollution since 1926. In the southern part of the lake, opposite of the lake outlet, effluents rich in copper and ammonia were discharged by a factory producing artificial silk. These effluents immediately affected the lake biocenosis, to the point that by 1930 the lake was considered as "sterile" (Monti 1930). From that point on, several studies have described the chemical and biological trends of the lake. A liming treatment was proposed to hasten the recovery of the lake after the effluent discharges were improved (Bonacina et al. 1988). This treatment began in 1989 and continued through 1990, for a total lake loading of 14,500 $\mathrm{t}$ limestone.

Four years after the lime treatment, samples were collected from previously used lake stations to allow a continuing assessment of temporal changes in the lake sediments. These assessments included chemical, toxicity, and benthic community characterisations. Chemical and toxicity testing was conducted on sediment core strata of 0-2 cm, 4-6 cm, 8-10 cm, and $18-20 \mathrm{~cm}$. Sampling stations included: Omegna, in the North Basin of the lake, close to the outlet and at $70 \mathrm{~m}$ depth; Station 45 in the Central Basin (143 m); and Buccione (35 m) in the South Basin near the silk factory effluent discharge.

\subsection{Sediment sampling}

Sediment cores were collected with a gravity coring device on June 20 (Buccione), 27 (St. 45), and July 4 (Omegna) 1994. Sediment core tubes (constructed of Plexiglass) were immediately capped with overlying water and held upright during transportation and processing. Sediments were returned to the laboratory and stored at $4{ }^{\circ} \mathrm{C}$ within 2 hours of collection. Five sediment cores were collected at each station. Sediment cores were sectioned at $2 \mathrm{~cm}$ intervals and the respective depth intervals composited from the 5 core replicates. These sediment depth sections were then subsampled for chemical analyses (15 -20 grams wet weight), whole sediment toxicity testing (80 to $100 \mathrm{~g}$ wet weight), and pore water toxicity testing (93 to $166 \mathrm{~g} \mathrm{wt}$ weight) within $24 \mathrm{hrs}$ of collection. Sediment subsamples were maintained at $4{ }^{\circ} \mathrm{C}$ until processing. All analyses were conducted within one week of collection. 


\subsection{Sediment characterisation}

Sediments were characterised using the following parameters: visual texture and colour, $\mathrm{pH}$ and main hydrochemical parameters in pore water and dry weight $\left(105{ }^{\circ} \mathrm{C}\right)$. Pore waters were collected by double centrifugation to better remove suspended solids. Sediments were spun once, then the supernatant gently decanted into another centrifuge bottle and spun a second time (each spin at $10,000 \times \mathrm{g}, 30$ minutes, $4{ }^{\circ} \mathrm{C}$ ). Hardness of the pore waters was $\sim 10 \mathrm{mg} \mathrm{l}^{-1} \mathrm{CaCO}_{3}$. The pore water varied in colour from light to dark yellow brown. Some samples showed slight turbidity despite the double centrifugation indicating the presence of colloidal materials.

\subsection{Toxicity assays}

The following toxicity assays were conducted:

1. Microtox $^{\mathrm{TM}}$ (Azure Corp., Carlsbad, California, USA): liquid (pore water) and solid phase assays at 15 and $30 \mathrm{~min}$. exposures using the luminescent bacteria, Vibrio fischeri;

2. Thamnotox Kit: (Ecotox, Milano, Italy) pore water exposure for $24 \mathrm{~h}$ using Thamnocephalus platyurus;

3. Rototox Kit: (Ecotox, Milano, Italy) pore water exposures for $24 \mathrm{~h}$ using Brachionus calyciflorus;

4. Cucumis sativus Seed Germination - Root Elongation: pore water and whole sediment exposures for 3 days;

5. Ceriodaphnia dubia whole sediment $7 \mathrm{~d}$ exposures; and

6. Hyalella azteca whole sediment $7 \mathrm{~d}$ exposures.

The rapid toxicity assays (Microtox, Thamnotox and Rotatox) were all conducted according to manufacturer's standard procedures. The pore water samples were warmed to room temperature and tested in a dilution series (4 to 13) of the pore water with replicates (1 to 6). Colour correction was applied in the Microtox assays due to the yellow-brown coloration of the pore water. The osmotic adjustment was $\mathrm{NaCl}$ or sucrose. The reference sediment was the top $2 \mathrm{~cm}$ sediment layer. The diluent for the Microtox was Microtox saline diluent and for the remaining two assays was Lake Maggiore water which has been shown to be free of contaminants. For the Rototox assay (Snell \& Persoone 1989), juveniles of B. calyciflorus were hatched from cysts and exposed for $24 \mathrm{~h}$ at $25^{\circ} \mathrm{C}$ in the dark. The Thamnotox assay used instar 2-3 larvae of the fairy shrimp T. platyurus.

The seed germination-root elongation test (Wang 1987) used cucumber (Cucumis sativus) seeds with either $5 \mathrm{ml}$ of pore water or $10 \mathrm{~g}$ wet sediments placed into a Petri dish, and covered with a Whatman $\mathrm{N}^{\circ} 1$ paper filter. Then 10 seeds were scattered on the filter. The Petri dishes were kept at $20{ }^{\circ} \mathrm{C}$ in the dark, and after 5 days the number of germinated seeds were counted and the root length measured at the next millimetre with a ruler. To combine these endpoints (seed germination and root elongation), results are expressed as a Germination Index, in per cent of the control ( $\% \mathrm{GI})$, according to the equation:

$$
\% \mathrm{GI}=100 \times\left(\mathrm{G}_{\mathrm{s}} \times \mathrm{L}_{\mathrm{s}}\right) /\left(\mathrm{G}_{\mathrm{c}} \times \mathrm{L}_{\mathrm{c}}\right)
$$

where: $G_{s}$ and $G_{c}$ are the number of germinated seeds in the sample and control, respectively; $\mathrm{L}_{\mathrm{s}}$ and $\mathrm{L}_{\mathrm{c}}$ are the lengths $(\mathrm{mm})$ of the roots in the sample and control.

The $C$. dubia and $H$. azteca assays were conducted using modified ASTM procedures (ASTM 1990). Cladocerans ( $<24 \mathrm{~h}$ old $)$ and amphipods ( $7-14 \mathrm{~d}$ old) were obtained from a Wright State University culture. Ten organisms each were randomly placed into duplicate $100 \mathrm{ml}$ beakers containing $15 \mathrm{ml}$ sediment and $60 \mathrm{ml}$ overlying water. The overlying water was reconstituted water with a hardness similar to Lake Orta $\left(10 \mathrm{mg} \mathrm{l}^{-1}\right.$ $\mathrm{CaCO}_{3}$ ). Test organisms were slowly acclimated to the soft water over a $24 \mathrm{~h}$ period prior to test initiation. Dissolved oxygen and temperature were measured on a daily basis. Hardness, alkalinity, conductivity, $\mathrm{pH}$, and ammonia were made at test initiation and termination. The test was conducted at $23{ }^{\circ} \mathrm{C}$ with a photoperiod of $16 \mathrm{~h}$ light and $8 \mathrm{~h}$ dark.

\subsection{Data analyses}

The Microtox assay effect levels were calculated using the Microtox statistical analysis software program, which calculates effect concentrations (EC1, EC10, EC20, and EC50) and associated 95\% confidence intervals for 15 and 30 minute exposure periods. Statistical significant differences and Pearson Correlation Coefficients were calculated using Statistica software.

\section{SEDIMENT CHARACTERISTICS}

At Station 45, undecomposed leaves were observed at core depths of 13 to $15 \mathrm{~cm}$ with gas pockets in the sediment from 13 to $17+\mathrm{cm}$. At Buccione, the top $2 \mathrm{~cm}$ were very oxidised, light brown, organic fluff with harpactoids. The 3 to $7 \mathrm{~cm}$ depth was very dark. Non-decomposed leaves were at $7 \mathrm{~cm}$ depth at the interface of light grey sediment that extended to $21 \mathrm{~cm}$ depth. At Omegna, the oxidised layer was to a depth of $1.5 \mathrm{~cm}$. Sediments were dark from 1.5 to $18 \mathrm{~cm}$ and then lighter in colour to the core bottom at $21 \mathrm{~cm}$. Gas pockets were observed from 10 to $13 \mathrm{~cm}$ of depth. The deep layer (ranging from 7 to $17 \mathrm{~cm}$ at the 3 sites) of sediment that contained undecomposed leaves and gas pockets appears to correspond with the period of greatest copper and ammonia inputs into the lake. The sediment characteristics in this layer suggests that organic matter decomposition processes were greatly reduced and anaerobic gas production was substantial (Adams \& Baudo 2001).

The chemical analyses of sediment grab samples from the same stations (Tab. 2, after Baudo et al. 2000) indicated a severe contamination in all three sites. More precisely, the distributions of metals along different 
Tab. 2. Metals ( $\left.\mathrm{mg} \mathrm{kg}^{-1}\right)$ in sediments (Ponar grab samples).

\begin{tabular}{lccccc}
\hline Stations & $\mathrm{Pb}$ & $\mathrm{Zn}$ & $\mathrm{Cu}$ & $\mathrm{Ni}$ & $\mathrm{Cr}$ \\
\hline Omegna & 484 & 465 & 1506 & 103 & 1932 \\
St. 45 & 334 & 500 & 1222 & 119 & 1769 \\
Buccione & 387 & 375 & 1127 & 92 & 739 \\
\hline
\end{tabular}

Tab. 3. Results of the assays with both porewater and sediment.

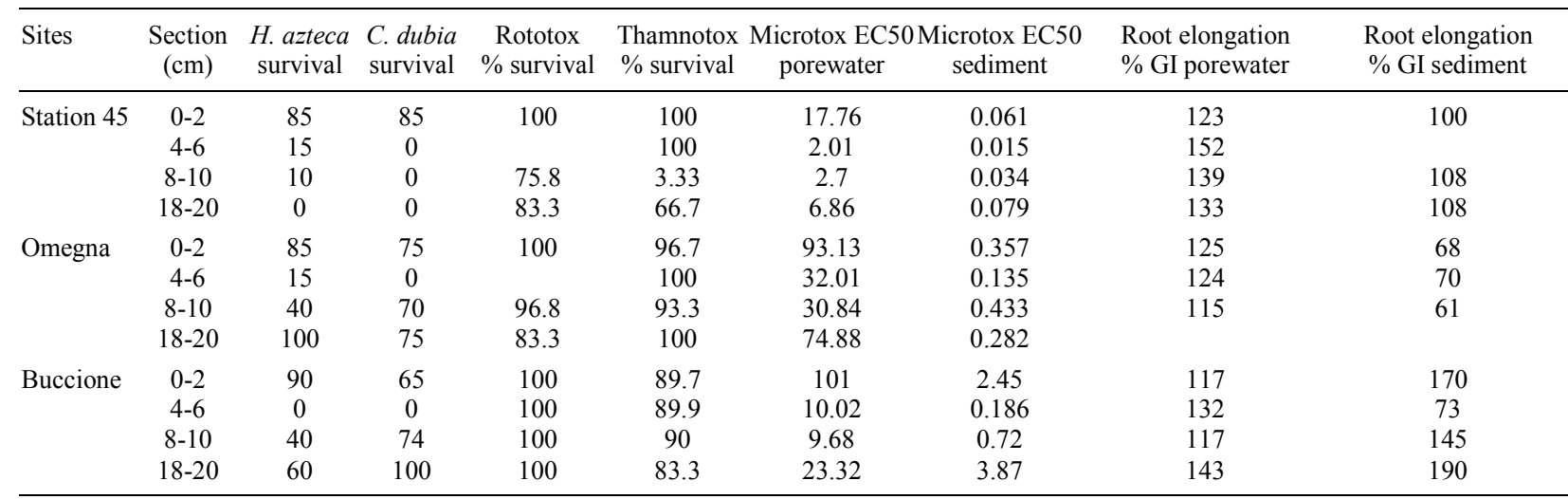

cores from Lake Orta (Beltrami et al. 1999) pointed out that over most of the lake the top layers of sediment are cleaner (by a factor of 2-3) than intermediate layers. Depending on the different sedimentation rate, the peak $\mathrm{Cu}$ levels in the South Basin were detected in the 6-8 $\mathrm{cm}$ section, decreasing to background levels under 18 $\mathrm{cm}$. For $\mathrm{Cr}$, the peak levels were at 4-6 $\mathrm{cm}$, decreasing sharply below $12 \mathrm{~cm}$. In the Central Basin, the peaks were at $8-10 \mathrm{~cm}$ for $\mathrm{Cu}$, and $6-8 \mathrm{~cm}$ for $\mathrm{Cr}$, respectively. But in North Basin, both $\mathrm{Cu}$ and $\mathrm{Cr}$ reached the maximum values in the $0-2 \mathrm{~cm}$ section. Hence, it is not surprising that toxicity results showed striking differences in toxicity associated with sediment depth and assay type (Tab. 3).

In general, the surficial sediments were not toxic; however deeper sediments ranged from $0 \%$ survival to non-toxic. Whole sediment tests showed C. dubia to be severely affected ( $0 \%$ survival) at all $4-6 \mathrm{~cm}$ depths throughout the lake (i.e., all 3 stations). Station 45 was the most toxic in general with acute toxicity observed at depths below the surficial zone for C. dubia, H. azteca, and Microtox pore water. The other two "Toxkits" (Rototox and Thamnotox) showed moderate to high toxicity at the $9-10 \mathrm{~cm}$ depth and the $19-20 \mathrm{~cm}$ depth. The Microtox solid phase and seed root elongation test responses showed little to no effect.

At the less toxic stations (Omegna and Buccione), there was less agreement between the Rototox, Thamnotox, Microtox and the invertebrate whole sediment assays. The invertebrate assays showed some toxicity at deeper depths ( 9 and $19 \mathrm{~cm}$ ), but varied from each other by 24 to $40 \%$ in survival. Of the remaining assays, only the Microtox pore water showed effects at these deeper depths.
Whole sediment assays using the invertebrates $H$. azteca and C. dubia were the most sensitive overall to sediment contamination, followed by the Microtox pore water assay. Of the Toxkits, Thamnotox was slightly more sensitive than the Rototox assay.

\section{DISCUSSION}

The root elongation tests with pore water showed a statistical significant stimulation in all three stations. This phenomenon, known as "hormesis" (Stebbing 1982), suggests that the organisms are reacting to a perturbed environment, possibly "diluting" toxicants in a larger mass of tissues (Barbero et al. 2001). For the whole sediment treatment, Station 45 showed no effect; at Buccione, top and bottom sections showed biostimulation, whereas a clearly toxic effect was detected in the 4-6 cm section; and at Omegna all sections resulted in an impaired germination index.

It is useful to compare response patterns to ascertain whether toxicity assay responses are similar. This can be viewed as redundant data, thus allowing only one or two assays to be used in future evaluations, or it can be viewed as a weight-of-evidence approach, where the two similar responses provide increased certainty of effects or no-effects. Having dissimilar responses is also important as it indicates that toxicity may exist for some species and not others (Burton et al. 1996). In this study the two invertebrates were significantly correlated $(r=$ $0.839, \mathrm{p}=0.0006)$. The two Toxkits responses were also similar $(r=0.729, p=0.016)$. Microtox pore water luminescence (EC50) also showed a significant correlation with $H$. azteca survival. Finally, a weak, but significant correlation, was observed between root growth in sediment $v s$ Microtox solid phase responses $(\mathrm{r}=$ 
$0.645, \mathrm{p}=0.032$ ). Based on these results, future evaluations of sediment and pore water toxicity in Lake Orta could be effectively conducted using the following 3 assays: C. dubia 7 day whole sediment, Microtox pore water, and Thamnotox. However, the Thamnotox did not provide unique information so it would be a low priority.

The necessity of using each of the above assessment components and the degree to which each is utilised is a site-specific issue. At sites of extensive chemical pollution, extreme habitat destruction or absence of desirable aquatic organisms, the impact can be clearly established with only one or two components, or simply qualitative measures. However, at most study sites, there will be "grey" areas where the ecosystem's integrity (quality) is less clear and should be measured via multiple components using a weight-of-evidence approach to evaluate adverse effects.

\section{ACKNOWLEDGMENTS}

We gratefully acknowledge the technical support of Ecotox LSD s.r.l. (Pregnana Milanese, Italy) for both Microtox and Toxkits testing.

\section{REFERENCES}

Adams, D.D. \& R. Baudo. 2001. Gases $\left(\mathrm{CH}_{4}, \mathrm{CO}_{2}\right.$ and $\left.\mathrm{N}_{2}\right)$ and pore water chemistry in the surface sediments of Lake Orta, Italy: acidification effects on $\mathrm{C}$ and $\mathrm{N}$ gas cycling. $J$. Limnol., 60(1): 79-90.

American Society for Testing and Materials (ASTM). 1990. Standard Guide for Conducting Sediment Toxicity Tests with Freshwater Invertebrates. ASTM. Philadelphia, PA. Annual Book of ASTM Standards. Vol. 11: ASTM Std. E 1383-90.

Barbero, P., M. Beltrami, R. Baudo \& D. Rossi. 2001. Assessment of Lake Orta sediments phytotoxicity after the liming treatment. J. Limnol., 60(2): 269-276.
Baudo, R. \& M. Beltrami. 2001. Chemical composition of Lake Orta sediments. J. Limnol., 60(2): 213-236.

Beltrami, M., D. Rossi \& R. Baudo. 1999. Phytotoxicity assessment of Lake Orta sediments. Aquatic Ecosystem Health and Management, 2: 391-401.

Bonacina, C., G. Bonomi, L. Barbanti, R. Mosello, D. Ruggiu \& G.A. Tartari. 1988. Lake Orta (N. Italy): Recovery after adoption of restoration plans. In: N.W. Schmidtke (Ed.), Toxic Contamination in Large Lakes: Impact of Toxic Contaminants on Fisheries Management. Lewis, Chelsea, MI: 101-130.

Burton, G.A. Jr. 1991. Assessing freshwater sediment toxicity. Environ. Toxicol Chem., 10: 1585-1627.

Burton, G.A. Jr. 1992. Sediment Toxicity Assessment. Lewis Publishers. Boca Raton, FL.: 457 pp.

Burton, G.A. Jr., C.G. Ingersoll, L.C. Burnett, M. Henry, M.L. Hinman, S.J. Klaine, P.F. Landrum, P. Ross \& M. Tuchman. 1996. A comparison of sediment toxicity test methods at three Great Lake Areas of Concern. J. Great Lakes Res., 22: 495-511.

LaPoint, T. \& W.T. Waller. 2000. Field assessment in conjunction with whole effluent toxicity testing. Environ. Toxicol. Chem., 19: 14-24.

Monti, R. 1930. La graduale estinzione della vita del Lago d'Orta. Rend. R. Ist. Lomb. Sc. Lett., 63: 3-22.

Plafkin, J.L., M.T. Barbour, K.D. Porter, S.K. Gross \& R.M. Hughes. 1989. Rapid bioassessment protocols for use in streams and rivers: benthic macroinvertebrates and fish. U.S. EPA, Washington, D.C.: EPA 440/4-89-001.

Snell, T.W. \& G. Persoone. 1989. Acute toxicity bioassays using rotifers. II. A freshwater test with Brachionus rubens. Aquatic Toxicology, 14: 81-92.

Stebbing, A.R.D. 1982. Hormesis - the stimulation of growth by low levels of inhibitors. Sci. Total Environ., 22: 213234.

U.S. EPA. 1990a. Technical support document for water quality-based toxics control. Office of Water. Washington, DC.

U.S. EPA. 1990b. Biological criteria: national program guidance for surface waters. Criteria and Standards Division. Washington, DC.: EPA 440/5-90/004.

Wang, W. 1987. Root elongation method for toxicity testing of organic and inorganic pollutants. Environ. Toxicol. Chem., 6: 409-414. 